\title{
Effects of Dietary Isoflavones on Proliferation and DNA Integrity of Myoblasts Derived from Newborn Piglets
}

\author{
MARCUS MAU, CLAUDIA KALBE, TORSTEN VIERGUTZ, GERD NÜRNBERG, AND CHARLOTTE REHFELDT \\ Muscle Biology and Growth Research Unit [M.M., C.K., C.R.], Reproductive Biology Research Unit [T.V.], Genetics and Biometry \\ Research Unit [G.N.], Research Institute for the Biology of Farm Animals, Dummerstorf, D-18196, Germany
}

\begin{abstract}
Soy-based formulas are consumed by growing numbers of infants and used as regular food supplements in livestock production. Moreover, constituent dietary phytoestrogens may compete with endogenous estrogens and affect individual growth. This study aimed to investigate the in vitro effects of isoflavones in comparison with estrogens on the proliferation of porcine satellite cells derived from neonatal muscle. After $7 \mathrm{~h}$ of exposure in serumfree medium, 17 $\beta$-estradiol $(1 \mathrm{nM}, 1 \mu \mathrm{M})$, estrone $(1 \mu \mathrm{M})$, and daidzein $(1,100 \mu \mathrm{M})$ slightly decreased whereas $100 \mu \mathrm{M}$ genistein substantially lowered DNA synthesis. Declines in DNA amount were observed with genistein $(1,100 \mu \mathrm{M})$ and daidzein $(100 \mu \mathrm{M})$. After $26 \mathrm{~h}$ of exposure, $100 \mu \mathrm{M}$ genistein reduced DNA synthesis, whereas it was increased by $10 \mu \mathrm{M}$ genistein and 10 and $100 \mu \mathrm{M}$ daidzein. In the case of $10 \mu \mathrm{M}$ genistein and $100 \mu \mathrm{M}$ daidzein, these increases apparently resulted from the repair of damaged DNA. Genistein and daidzein $(100 \mu \mathrm{M})$ reduced protein synthesis, caused a $\mathrm{G}_{2} / \mathrm{M}$ phase block, and decreased DNA amount in association with higher rates of cell death partially resulting from apoptosis. Conclusively, isoflavones at concentrations of greater than $1 \mu \mathrm{M}$ act as inhibitors of porcine skeletal muscle cell proliferation. (Pediatr Res 63: 39-45, 2008)
\end{abstract}

$\mathrm{P}$ ant-derived steroid-like dietary compounds such as isoflavones display estrogenic activity in humans and animals and thus are referred to as phytoestrogens (1). Generally, phytoestrogens are comprised of two major classes, the lignans and the flavonoids (2). In addition to isoflavans and coumestans, the flavonoids include the isoflavones, such as genistein and daidzein, which reach high concentrations in legumes, especially soy (0.2-1.6 mg/g dry weight) (3), which is widely used in human nutrition and one of the most important food supplements in livestock production.

Isoflavones have been shown to exhibit multibiologic properties (2). First, they were demonstrated to exert estrogenic and anti-estrogenic effects, acting as estrogen receptor agonists or antagonists and thereby influencing cellular metabolism $(4,5)$. Second, isoflavonic phytoestrogens, especially genistein, are indicated to have inhibitory effects on protein tyrosine kinases $(5,6)$. Third, genistein has been shown to influence cell cycle progression in cultures of various growing cancer cell lines by blocking the cells during $\mathrm{G}_{2} / \mathrm{M}$ phase

Received June 4, 2007; accepted August 4, 2007.

Correspondence: Charlotte Rehfeldt, Ph.D., Muscle Biology and Growth Research Unit, Research Institute for the Biology of Farm Animals, Wilhelm-Stahl-Allee 2, Dummerstorf, D-18196, Germany; e-mail: rehfeldt@fbn-dummerstorf.de

Funded by the Deutsche Forschungsgemeinschaft Project: Re 978/11-1 and WilhelmSchaumann Foundation.
(7-9) and is therefore a significant inhibitor of in vitro cell growth $(8,10)$. At high concentrations, genistein may also induce apoptosis (11) and cause DNA damage by directly influencing topoisomerase II activity (12).

However, the consumption of soy isoflavones is mainly considered to afford beneficial health properties, especially during human menopause and for cancer prevention $(5,13)$. As with human nutrition, soy is a commonly used food supplement in pig production, and therefore constituent phytoestrogens could influence pig growth performance (14). In this context, isoflavones have been shown to stimulate the growth of weanling pigs (Cook, dissertation, 1998, Iowa State University). Contradictory results were obtained on the influence of maternal daidzein on birth weight of the offspring $(15,16)$. When various cell lines have been directly exposed to isoflavones in culture, cellular growth or genetic stability was found to be adversely affected in most cases $(8,13,17)$. Genistein or daidzein also reduced the growth or differentiation of rodent skeletal muscle cell lines $(10,18,19)$ in a dose-dependent manner. The concentration of genistein required to inhibit in vitro cell growth was shown to be high, usually $10 \mu \mathrm{M}$ or greater. In comparison, plasma concentrations of isoflavones in adult pigs fed a typical soy-based diet reached approximately $1 \mu \mathrm{M}$ (14). However, piglets fed soy supplements in amounts typical for soy-infant formulas showed a serum concentration of genistein of $2.36 \pm 2.26 \mu \mathrm{M}$ on average, which was nearly identical to the mean serum concentration of $2.53 \pm 1.64 \mu \mathrm{M}$ in human infants (20). The piglet likely mimics the human infant's physiology and therefore represents a good model to investigate the effects of dietary isoflavones on the development of cells, tissues, and organs both in vivo and in vitro. So far, the impact of isoflavones and estrogens on the growth and metabolism of porcine skeletal muscle has received very little attention. Only recently have the estrogen receptors $\alpha$ and $\beta$ (ER $\alpha, \operatorname{ER} \beta)$, potential targets for estrogenic and isoflavonic actions, been shown to be expressed in porcine skeletal muscle (21).

This in vitro study aimed to investigate the direct effects of genistein and daidzein in comparison with estrogens on proliferating satellite cell cultures derived from neonatal pig skeletal muscle. We hypothesized that isoflavones at high

\footnotetext{
Abbreviations: CA, cytosine arabinoside; E1, estrone E2, 17 $\beta$-estradiol; LDH, lactate dehydrogenase (EC 1.1.1.27); SFGM, serum-free growth medium
} 
concentrations would adversely affect muscle cell growth and at low concentrations would promote proliferation. The applied dosages mimicked regular isoflavone concentrations of soy-based diets and included isoflavone concentrations that have been measured in serum after the consumption of soyinfant formulas or porcine forage crops.

\section{METHODS}

Muscle primary cell culture. This study was approved according to the regulations of the FBN Dummerstorf. The right and left semimembranosus muscles from nine ( 5 male, 4 female) newborn German Landrace piglets were excised and trimmed of visible connective tissue. Digestion of tissue to release myogenic cells was carried out according to a modification of a protocol based on Harper et al. (22). Satellite cells were enriched by using a Percoll (Sigma Chemical Co., St. Louis, MO) gradient (90, 40, 25\% in phosphate-buffered saline) according to the method of Roe et al. (23). To obtain a uniform stock of cells for various experiments, a pool was established from all cells collected during several preparation procedures, as described previously (21). The percentage of muscle satellite cells was determined by immunostaining for desmin and subsequent flow cytometry (Beckman Coulter, Fullerton, CA) (21). Fluorescence analysis yielded 95\% desmin-positive cells.

DNA and protein synthesis. Cells were seeded in gelatin-coated 96-well microplates at approximately $5 \times 10^{3}$ cells per well and grown for $1 \mathrm{~d}$ in minimum essential medium $\alpha(\mathrm{MEM} \alpha)$ :MCDB 110 (medium complete with trace elements, $4: 1$ ) plus $10 \%$ fetal calf serum and $10 \%$ horse serum. In DNA synthesis experiments, cells were treated with $17 \beta$-estradiol (E2; Sigma Chemical Co.), estrone (E1; Sigma Chemical Co.), genistein, and daidzein (Sigma Chemical Co.) in serum-free growth medium (SFGM) consisting of $\operatorname{MEM} \alpha$ (phenol red-free):MCDB 110 (4:1) supplemented according to the method of Doumit et al. (24) for $7 \mathrm{~h}$ (short-term exposure) or $26 \mathrm{~h}$ (long-term exposure). In each of two to four independent experiments, a total of eight wells spread over two plates were used for each concentration of E2 $(0.1 \mathrm{nM}$; $1 \mathrm{nM} ; 1 \mu \mathrm{M})$, E1 $(1 \mathrm{nM} ; 1 \mu \mathrm{M})$, and of genistein and daidzein $(0.1 \mu \mathrm{M} ; 1$ $\mu \mathrm{M} ; 10 \mu \mathrm{M} ; 100 \mu \mathrm{M})$. In protein synthesis experiments, the effects of selected concentrations of genistein and daidzein were tested over $26 \mathrm{~h}$ in two experiments (each with a total of eight wells per concentration). Both DNA and protein synthesis were measured during the last $6 \mathrm{~h}$ of the incubation period. To measure DNA synthesis rate, the monolayers were labeled with 10 $\mu \mathrm{L}$ medium per well containing $7.4 \mathrm{kBq}(0.2 \mu \mathrm{Ci})\left[{ }^{3} \mathrm{H}\right]$-thymidine $(50.0$ $\mathrm{Ci} / \mathrm{mM}$, Amersham Biosciences, Little Chalfont, UK). In some experiments, $\left[{ }^{3} \mathrm{H}\right]$-thymidine incorporation was blocked by supplementing the medium with $1 \mu \mathrm{M}$ cytosine arabinoside (CA; Sigma Chemical Co.). To measure protein synthesis rate, the monolayers were labeled with $20 \mu \mathrm{L}$ medium per well containing $148 \mathrm{kBq}(4 \mu \mathrm{Ci}) \mathrm{L}-\left[2,6-{ }^{3} \mathrm{H}\right]$-phenylalanine $(56.0 \mathrm{Ci} / \mathrm{mM}$, batch 94 , Amersham Biosciences). In both experimental types, the medium was removed after $6 \mathrm{~h}$. Combined assays of radioactivity as well as DNA or protein contents in monolayers were carried out as described previously (25).

Cell cycle analysis. Cell cycle analysis of porcine muscle satellite cells seeded at $5 \times 10^{4}$ cells in gelatin-coated 24-well plates was performed by flow cytometry (26) after $26 \mathrm{~h}$ of exposure to 10 and $100 \mu \mathrm{M}$ of genistein and daidzein in SFGM.

Measurement of lactate dehydrogenase activity. Cells were incubated with $1 \mu \mathrm{M} \mathrm{E} 2$ and 10 and $100 \mu \mathrm{M}$ genistein or daidzein for $26 \mathrm{~h}$, respectively, in three repeated experiments. Lactate dehydrogenase (LDH) activity was measured in cell culture supernatants according to the method of Legrand $e t$ al. (27) using a Spectramax 250 plate reader (Molecular Devices Corporation, Sunnyvale, CA). LDH activity was expressed as International Unit per milliliter of supernatant, the enzyme activity, which converts $1 \mu \mathrm{M} \mathrm{NADH/}$ $\mathrm{min} / \mathrm{mL}$ to NAD at $25^{\circ} \mathrm{C}$.

Measurement of apoptosis. Cells were plated at $5 \times 10^{3}$ cells per well in gelatin-coated 96 -well cell culture plates and grown for $24 \mathrm{~h}$, followed by a 26-h treatment with genistein and daidzein $(10,100 \mu \mathrm{M})$. Caspase-3 activity in muscle cells was measured using the fluorometric NucView 488 caspase-3 substrate assay (Biotium, Inc., Hayward, CA).

Comet assay. In two replicates, $10^{5}$ cells were grown in gelatin-coated 35 $\mathrm{mm}$ dishes for $24 \mathrm{~h}$ and then treated with genistein and daidzein $(10,100 \mu \mathrm{M})$ in SFGM for $26 \mathrm{~h}$. Cells of the first replicate were harvested using a rubber policeman. Cells of the second replicate were grown for additional $7 \mathrm{~h}$ in SFGM without isoflavones before harvest. All following steps were performed in accordance with the manufacturer's instructions (Trevigen Comet assay Kit TA800, Gaithersburg, MD), and 600 to 800 cells per treatment were counted. The Comets were classified by the grade of damage (Fig. 1) using the image analysis system IMAGE C (Imtronic GmbH, Berlin, Germany).

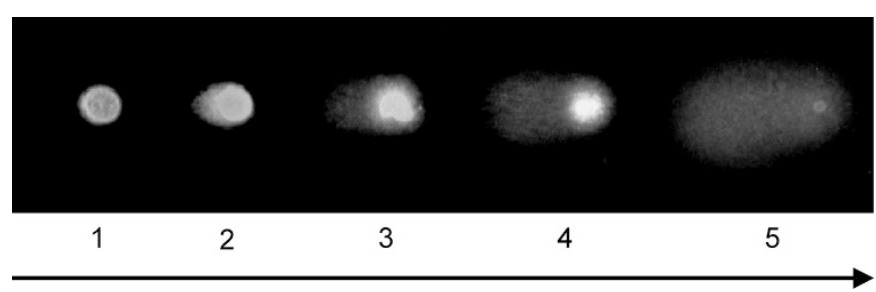

Figure 1. Classification of DNA damage in porcine skeletal myoblasts using the Comet assay (1). Class 1, no damage; (2-4); classes 2 to 4: intermediate (slight, medium, and high) damage; (5) class 5, severe damage.

Statistical analysis. Data were subjected to analyses of variance using the GLM or MIXED procedure of SAS (version 9.1, SAS Institute, Inc., Cary, NC) with treatment and replicate as fixed factors and plate as random factor, if applicable. Data given in the graphs are least squares means. Significance of differences between least squares means was tested by the Tukey test $(p<0.05)$.

\section{RESULTS}

DNA synthesis rate and accumulation. After $7 \mathrm{~h}$ of exposure, DNA synthesis was slightly decreased by E2 $(1 \mathrm{nM} ; 1$ $\mu \mathrm{M})$ and $\mathrm{E} 1(1 \mu \mathrm{M})$ and by 1 and $100 \mu \mathrm{M}$ of daidzein (Fig. $2 A$ and $B)$. DNA synthesis was substantially lowered $(-74 \%)$ with $100 \mu \mathrm{M}$ genistein. The decreases in DNA synthesis rate were accompanied by a reduction in DNA under the influence of both genistein $(1,100 \mu \mathrm{M})$ and daidzein $(100 \mu \mathrm{M})$, with the highest decreases observed at $100 \mu \mathrm{M}$ (Fig. 2D). Estrogens did not affect the DNA amount (Fig. 2C).

In response to long-time exposure ( $26 \mathrm{~h}$ ), changes in DNA synthesis and DNA amount were observed neither with E1 nor with E2 (Fig. $3 A$ and $C$ ). The effects of $100 \mu \mathrm{M}$ genistein on DNA synthesis $(-89 \%)$ and DNA amount $(-31 \%)$ were again highly negative (Fig. $3 B$ and $D$ ). In contrast, significant increases in DNA synthesis were observed with $10 \mu \mathrm{M}$ genistein $(+106 \%)$ and 10 and $100 \mu \mathrm{M}$ daidzein $(+31 \%$, $+79 \%$ ) (Fig. 3B). Surprisingly, the increases in DNA synthesis were accompanied by significant decreases in DNA amount in the case of $10 \mu \mathrm{M}$ genistein and $100 \mu \mathrm{M}$ daidzein, and with $10 \mu \mathrm{M}$ daidzein the DNA amount was unchanged (Fig. 3D). To further elucidate these conflicting results, we blocked DNA synthesis rate with CA. After the addition of 1 $\mu \mathrm{M}$ CA to the cell culture medium, the increase in DNA synthesis under the influence of genistein $(10 \mu \mathrm{M})$ and daidzein $(10,100 \mu \mathrm{M})$ was specifically inhibited during the $26 \mathrm{~h}$ of treatment (Fig. 4A). According to the effect of CA to prevent the cells from DNA synthesis, no differences in DNA amount were observed among CA-blocked cultures of control, $10 \mu \mathrm{M}$ genistein, and daidzein (Fig. 4B). Even a decrease was seen in CA-blocked cultures with $100 \mu \mathrm{M}$ daidzein, which is indicative of cell loss. In comparing the unblocked cultures with the corresponding CA-blocked cultures, almost equal increases in DNA amount occurred in the control culture and the culture treated with $10 \mu \mathrm{M}$ daidzein during the 26-h treatment period. No additional DNA accumulated with 10 $\mu \mathrm{M}$ genistein and $100 \mu \mathrm{M}$ daidzein within this period. Therefore, surprisingly, the increased rates of DNA synthesis were not associated with increases in DNA content, suggesting that the effects may not be caused by increased cell proliferation. 


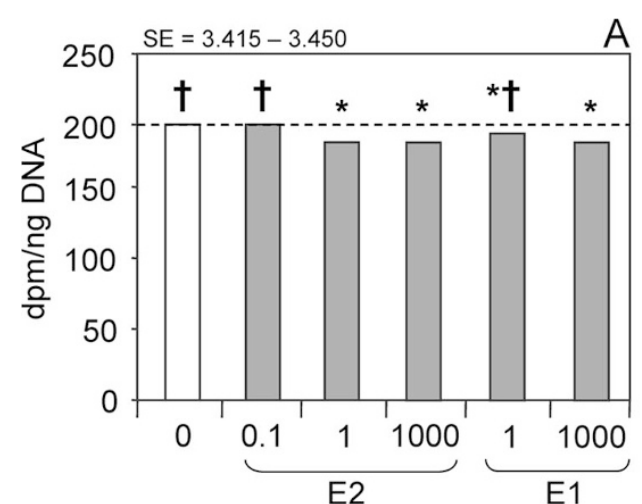

Effector concentration ( $\mathrm{nM}$ )

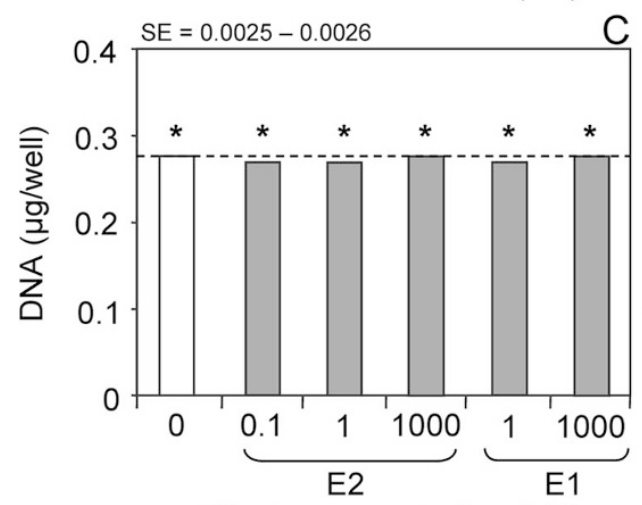

Effector concentration (nM)
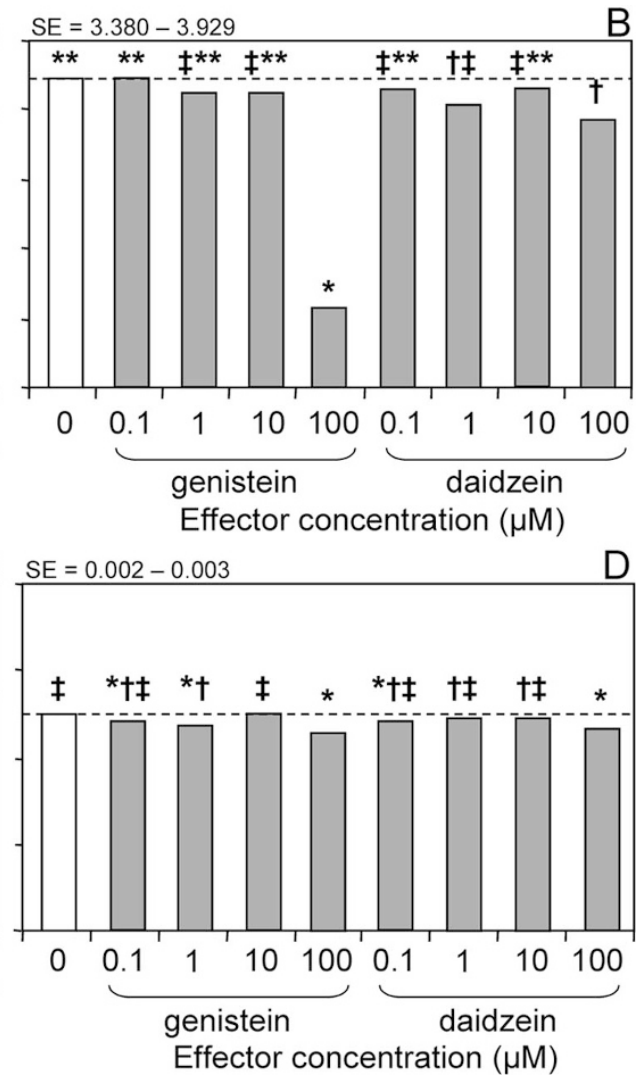
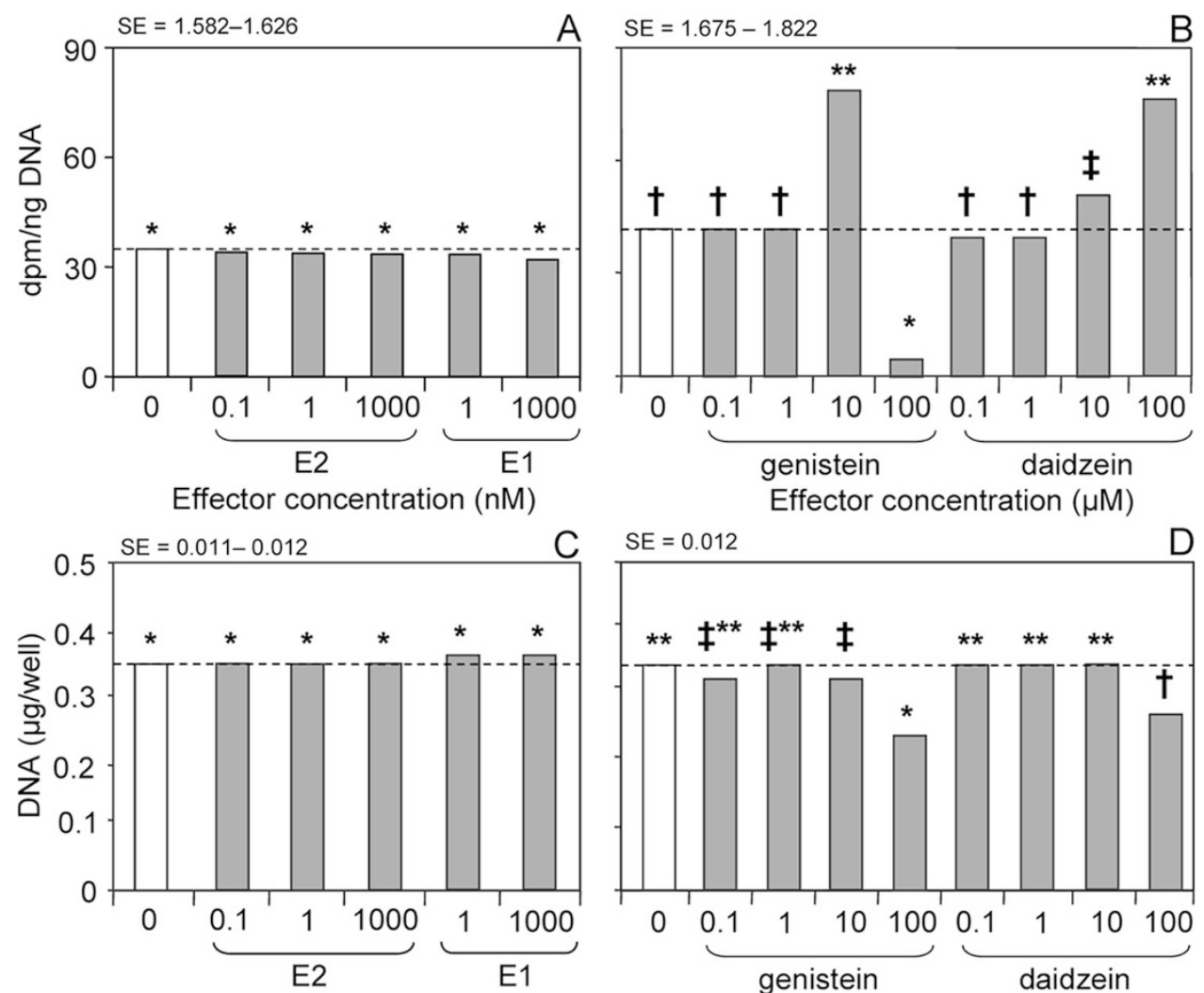

Effector concentration ( $\mathrm{nM}$ )

Figure 2. Short-term effects $(7 \mathrm{~h})$ of different concentrations of E2, E1, genistein, and daidzein on porcine myoblast proliferation measured as $\left[{ }^{3} \mathrm{H}\right]$-thymidine incorporation $(A, B)$ and DNA amount $(C, D)$. Values are least squares means. $(A, C) n=$ $32 ;(B, D) n=24$. Bars without common symbols differ significantly $(p<0.05)$.
Figure 3. Long-term effects ( $26 \mathrm{~h}$ ) of different concentrations of E2, E1, genistein, and daidzein on porcine myoblast proliferation measured as $\left[{ }^{3} \mathrm{H}\right]$-thymidine incorporation $(A, B)$ and DNA amount $(C, D)$. Values are least squares means. $(A, C) n=$ $24 ;(B, D) n=16$. Bars without common symbols differ significantly $(p<0.05)$.
Protein synthesis rate. If DNA synthesis under the influence of $10 \mu \mathrm{M}$ genistein and 10 and $100 \mu \mathrm{M}$ daidzein increased as a result of real de novo synthesis caused by proliferation, protein synthesis should also be stimulated. Conversely, after $26 \mathrm{~h}$ of incubation, both $100 \mu \mathrm{M}$ genistein $(-32 \%)$ and daidzein $(-36 \%)$ dramatically reduced whereas 

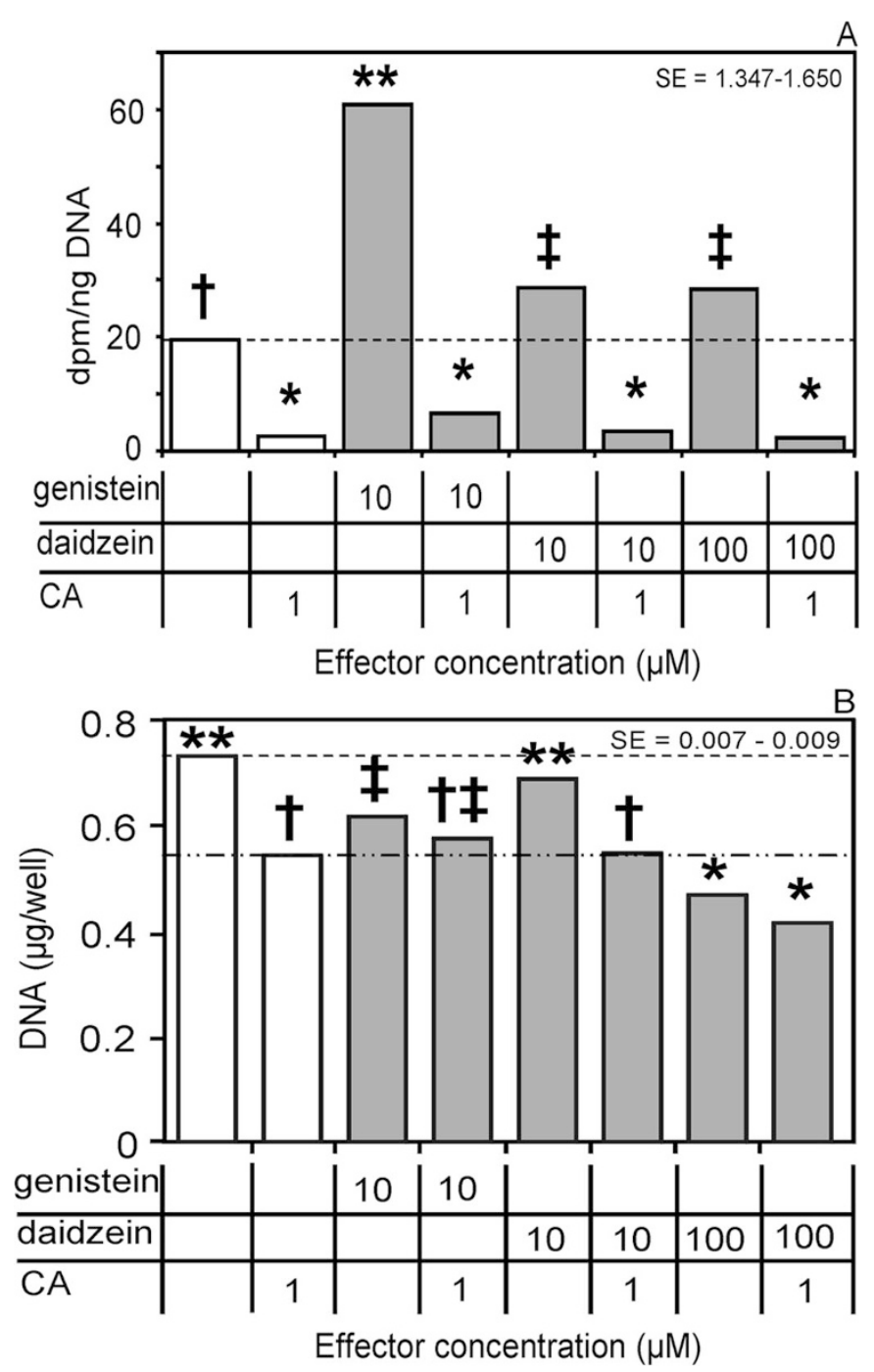

Figure 4. $\left[{ }^{3} \mathrm{H}\right]$-thymidine incorporation $(A)$ and DNA amount $(B)$ of porcine semimembranosus myoblasts exposed to selected concentrations of genistein and daidzein in the absence or presence of $1 \mu \mathrm{M}$ cytosine arabinoside (CA) for $26 \mathrm{~h}$. Least squares means are reported for each treatment, $n=6$. Values in a panel without common symbols differ significantly $(p<0.05)$.

$10 \mu \mathrm{M}$ genistein or daidzein did not change protein synthesis (data not shown). Also, protein amount was reduced by genistein $(10,100 \mu \mathrm{M})$ and daidzein $(100 \mu \mathrm{M})$.

Cell cycle analysis. To further unravel possible reasons for the observed discrepancy between lower DNA amounts and higher DNA synthesis rates, the cell cycle of the adherent cells was analyzed after $26 \mathrm{~h}$ of exposure to 10 and $100 \mu \mathrm{M}$ of daidzein and genistein (Fig. 5). At a concentration of $10 \mu \mathrm{M}$, daidzein did not change cell cycle processes, whereas under the influence of $10 \mu \mathrm{M}$ genistein, the number of S-phase cells was reduced from 14 to $11 \%(p<0.05)$. At a concentration of $100 \mu \mathrm{M}$, genistein obviously caused a $\mathrm{G}_{2} / \mathrm{M}$-phase block in cell cycle and a slight increase in S-phase cells $(p<0.05)$, whereas with $100 \mu \mathrm{M}$ daidzein, a tendency for the $\mathrm{G}_{2} / \mathrm{M}$ block was observed $(p<0.10)$. Cell cycle analysis did not reveal increases in the proportion of S-phase cells for those isoflavone concentrations (10, $100 \mu \mathrm{M}$ daidzein, $10 \mu \mathrm{M}$ genistein) that induced higher DNA synthesis rates.

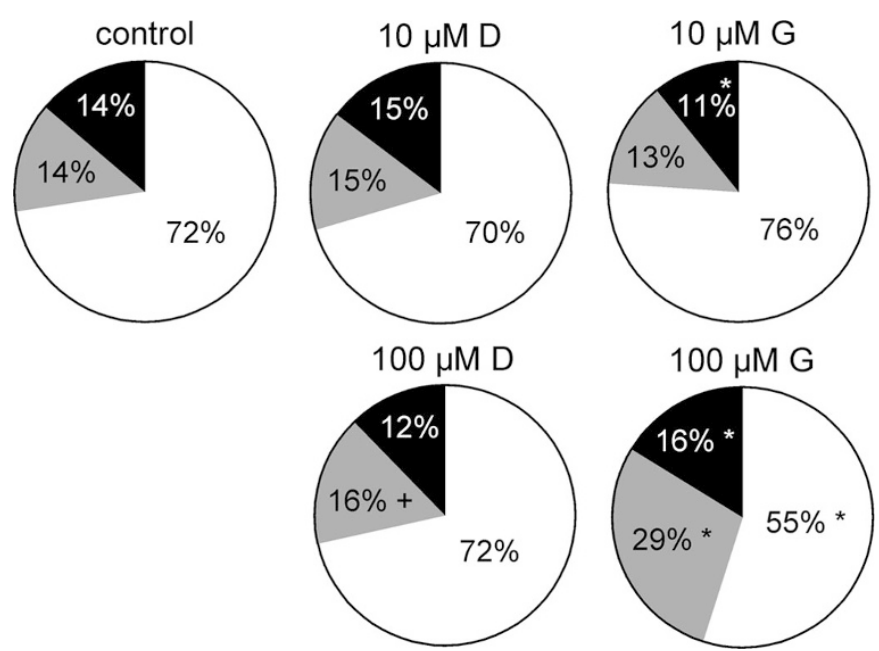

Figure 5. Effects of $26 \mathrm{~h}$ exposure to 10 and $100 \mu \mathrm{M}$ genistein $(\mathrm{G})$ or daidzein (D) on the cell cycle of porcine myoblasts. Values are the percentage of the cell population in $\mathrm{G}_{0} / \mathrm{G}_{1}(\square), \mathrm{G}_{2} / \mathrm{M}(\square)$, and $S$ phase ( $\square$ ) of cell cycle, $n=5$. $* p<0.05,+p<0.10$ for differences to control.

Cell death and DNA damage and repair. Lower DNA amounts imply that the cultured porcine muscle cells are damaged or dying under the influence of isoflavones. Therefore, LDH activity was measured in the cell culture supernatants after exposure to selected effector concentrations as a marker for cell death (27). Both genistein and daidzein did not change LDH activity compared with the untreated control at a concentration of $10 \mu \mathrm{M}$. However, $100 \mu \mathrm{M}$ daidzein approximately doubled LDH activity compared with the control, whereas the exposure to $100 \mu \mathrm{M}$ genistein resulted in a 2.5 -fold increase of LDH activity (Fig. 6). To elucidate whether cell death was caused by apoptosis, the monolayers were tested for caspase- 3 activity. With use of daidzein at concentrations of 10 and $100 \mu \mathrm{M}$ and genistein at $10 \mu \mathrm{M}$, no caspase- 3 activity was observed. After $26 \mathrm{~h}$ of exposure to 100 $\mu \mathrm{M}$ genistein, up to 20 single cells per $1 \mathrm{~mm}^{2}$ were detected to react positively to caspase- 3 activity, indicating apoptosis (not shown).

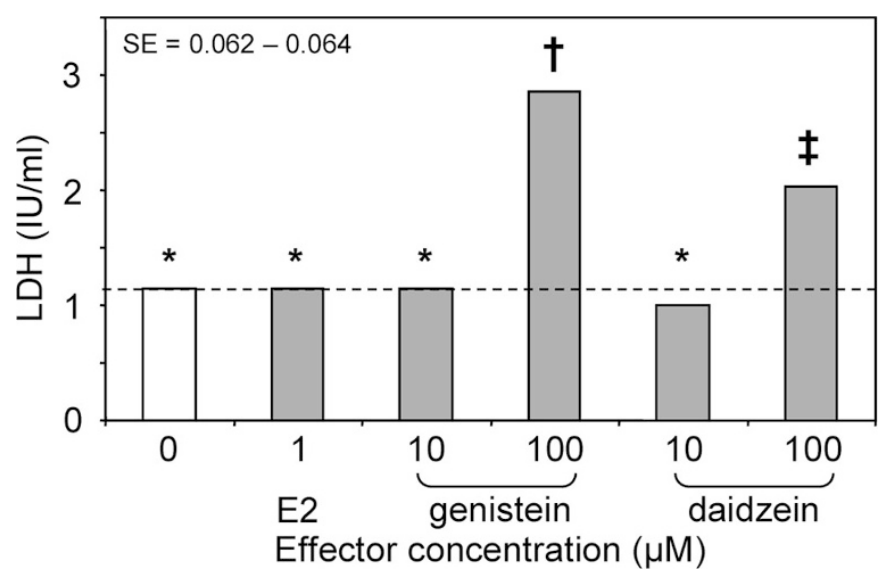

Figure 6. Viability of porcine semimembranosus myoblasts after $26 \mathrm{~h}$ of exposure to selected concentrations of E2, genistein, and daidzein. Bars represent the least squares means for $\mathrm{LDH}$ activity, $n=42-45$. Bars bearing common symbols differ significantly $(p<0.05)$. 
The Comet assay was used to reveal the occurrence of DNA damage that could cause the activation of different DNA repair mechanisms, which are supposed to cause higher thymidine incorporation. Figure 7 shows the relative frequency of different classes of DNA damage measured after $26 \mathrm{~h}$ of incubation with isoflavones and after an additional $7 \mathrm{~h}$ in isoflavone-free medium. After $26 \mathrm{~h}$ of exposure (Fig. 7A), the numbers of slightly damaged (class 2 ) and nondamaged cells (class 1) were not different with any of the isoflavone concentrations used when compared with the control. With $100 \mu \mathrm{M}$ daidzein, the proportion of highly damaged cells (class 3 ) was increased compared with control cells $(p=0.08)$. With 10 $\mu \mathrm{M}$ genistein, the number of highly damaged cells (classes 3-5) was also numerically higher than in control cultures (8.8 vs $4.6 \%$ ). The low proportion of highly damaged cells in the

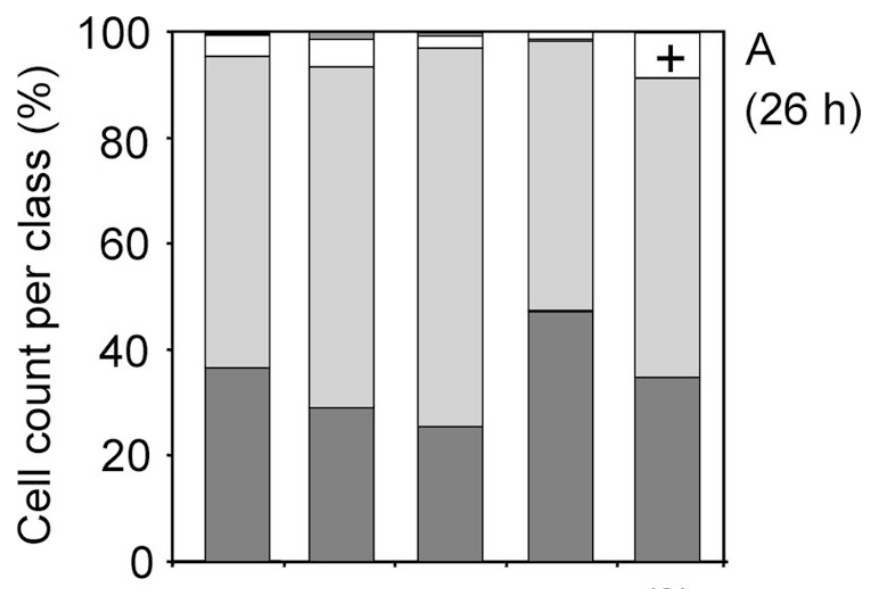

(3)

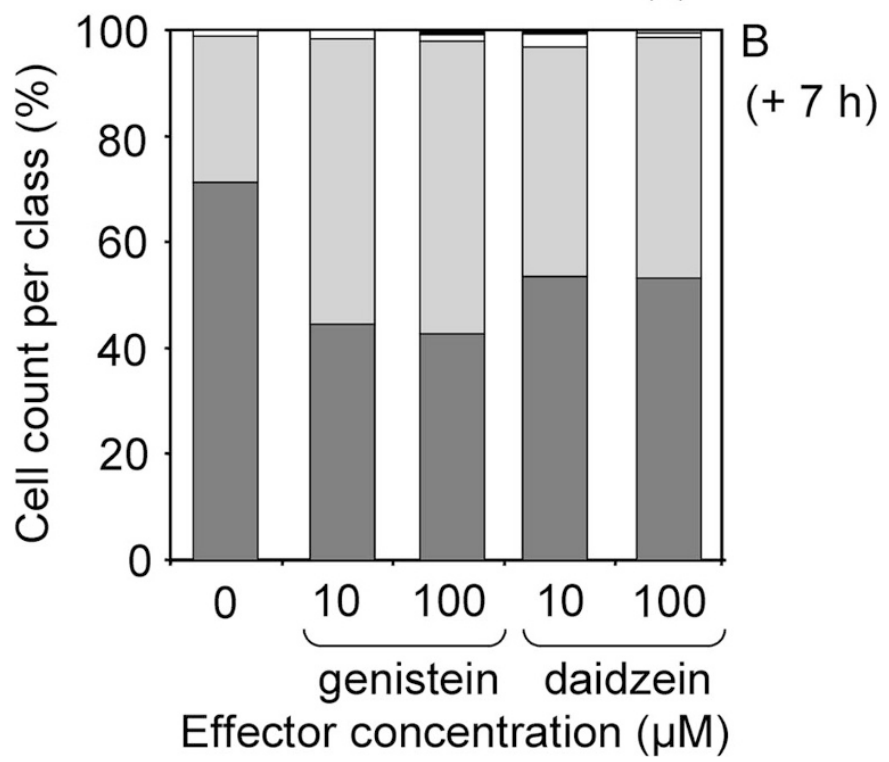

Figure 7. DNA damage induced by genistein and daidzein in porcine satellite cell cultures measured by the Comet assay. Columns show the relative frequency (based on least squares means) of different classes of DNA damage ( $\square$ class 1 ; $\square$ class $2 ; \square$ class $3 ; \square$ class 4 ; $\square$ class 5 ) measured $(A)$ after $26 \mathrm{~h}$ of incubation with isoflavones and $(B)$ after additional $7 \mathrm{~h}$ in isoflavone-free medium to evaluate DNA repair activity. Cell counts are based on 600-800 cells per group. $+p<0.10$ indicates differences between treatment group and control. 3 , difference in class 3 within treatment between $26 \mathrm{~h}$ and $26+7 \mathrm{~h}$ $(p<0.05)$. samples that were exposed to $100 \mu \mathrm{M}$ genistein results apparently from preceding cell loss.

After an additional $7 \mathrm{~h}$ in isoflavone-free medium (Fig. 7B), DNA repair was measured as an increase in the number of undamaged cells (class 1) and an associated decrease in the number of damaged cells. DNA repair was observed in the control by tendencies ( $p=0.12-0.16$ ) for increases of undamaged cells and decreases of damaged cells in classes 2 and 3 . The number of highly affected cells (class 3 ) was also numerically reduced in the samples treated before with $10 \mu \mathrm{M}$ genistein (to one third; $p=0.04$ with the more liberal $t$ test) and significantly lower in the samples treated before with 100 $\mu \mathrm{M}$ daidzein $(p<0.05)$, those concentrations that caused a doubling in DNA synthesis rates (Fig. $3 B$ ). DNA damage in isoflavone-treated cells tended to be repaired more slowly or less effectively compared with control cells. No significant repair activity was detected after removal of $10 \mu \mathrm{M}$ daidzein and $100 \mu \mathrm{M}$ genistein.

\section{DISCUSSION}

Growing numbers of infants consume soy-based products and consequently are exposed to high concentrations of isoflavones (20). However, little attention has been directed toward possible effects of genistein and daidzein on postnatal growth performance or skeletal muscle development. By the establishment of a satellite cell culture derived from semimembranosus muscle of newborn piglets, we provided an appropriate in vitro model to study skeletal muscle cell growth and differentiation under the influence of dietary isoflavonic phytoestrogens and any other bioactive compounds.

In the pig, estrogens are generally not considered to effectively enhance muscle growth (28). From our findings, we conclude that estrogens exhibit almost no effects on in vitro porcine skeletal muscle cell proliferation at physiologic concentrations. Nevertheless, at supraphysiologic concentrations, estrogens temporarily inhibited DNA synthesis in porcine skeletal muscle cells, which is in agreement with findings that demonstrated $\mathrm{E} 2$ to reduce $\mathrm{L}_{6}$ skeletal muscle cell growth at a supraphysiologic concentration of $2.5 \mu \mathrm{M}$ (18). We therefore conclude that neither estrogens nor isoflavones are able to stimulate proliferation of porcine myoblasts by way of the estrogenic pathway. In contrast, inhibitory effects on proliferation cannot be excluded.

Indeed, our findings suggest that genistein beyond $1 \mu \mathrm{M}$ and daidzein beyond $10 \mu \mathrm{M}$ act as toxins and inhibitors of porcine muscle cell growth. However, because there was no increased cell damage or cell death but an increase in DNA synthesis with $10 \mu \mathrm{M}$ daidzein, we suggest that at this concentration, daidzein exerts no negative effects on the proliferation of porcine skeletal muscle cells. Consistent with our results, a $24 \mathrm{~h}$ exposure to $3.7 \mu \mathrm{M}$ genistein was demonstrated to cause an increase in thymidine incorporation into the DNA of human $\mathrm{CaCo} 2-\mathrm{BBe}$ cells, although an increase in cell number has not been observed (7). In addition, at concentrations of 26 to $111 \mu \mathrm{M}$, genistein decreased thymidine incorporation, and cell number dropped by $40 \%$ after the exposure to $111 \mu \mathrm{M}$ genistein (7). With respect to skeletal muscle, 
genistein blocked cell proliferation at concentrations of 1 to 10 $\mu \mathrm{M}$ in $\mathrm{L}_{6}$ and $\mathrm{L}_{8}$ rat myoblasts $(10,18)$. In agreement with our results, the effects of daidzein were less pronounced than those of genistein (18).

Evidence for negative effects of genistein on DNA integrity have been found in miscellaneous cancer cell lines (17). To ensure the integrity of the cell and its genetic material, cell cycle events must follow a well-defined sequence, which is guaranteed by special checkpoint signaling pathways (29). The G2 checkpoint is activated by the inhibition of topoisomerase II in response either to DNA damage or incomplete DNA replication (30). Generally, checkpoints halt the cell cycle machinery and allow time for a process such as DNA replication or repair to be completed (29). In this context, we observed high concentrations of both genistein and daidzein to cause cell cycle arrest in G2/M phase and cell death, with greater effects seen with genistein. The Comet assay revealed high-grade DNA damage and subsequent repair apparently to occur in response to $10 \mu \mathrm{M}$ genistein and $100 \mu \mathrm{M}$ daidzein. Consequently, the compensation of high-grade DNA damage instead of de novo DNA synthesis is concluded to be the cause of the increased DNA synthesis rates observed with these concentrations. Importantly, increased DNA synthesis rate is not adequate evidence of increased cell proliferation in the presence of isoflavones.

Concerning cell cycle control, genistein has been demonstrated not only to inhibit topoisomerase II activity $(11,12)$ but also receptor tyrosine kinases such as epidermal growth factor-receptor (EGFR) $(6,31)$ or insulin-like growth factorreceptor type 1 (32). Bai et al. (33) showed that genistein at a concentration of $10 \mu \mathrm{M}$ down-regulated gene expression of the EGFR signaling pathway in Panc 1 cell lines. Because high concentrations of genistein were shown to inhibit cell growth of both estrogen-dependent and estrogen-independent cells (34), the antiproliferative effect of genistein is suggested to mainly originate from the inhibition of tyrosine kinase activity (8). Interestingly, the inhibition of topoisomerase II and receptor tyrosine kinases has been found to be essential for the induction of DNA damage (35) and apoptosis $(8,32)$. However, the removal of genistein from cell culture medium facilitated the cells reentering the cell cycle (9).

In summary, novel knowledge on the influence of dietary isoflavones on porcine skeletal muscle growth can be derived from this study. The results suggest that isoflavonic phytoestrogens directly affect in vitro porcine muscle cell growth, with the effects being dose and time dependent. Contrary with our hypothesis, low isoflavone concentrations of 0.1 and $1 \mu \mathrm{M}$ did not affect muscle cell proliferation in vitro, although they were discussed previously to promote postnatal growth in piglets (Cook, dissertation, 1998, Iowa State University). However, positive effects in vivo could also result from indirect systemic actions of isoflavones. On the other hand, isoflavones could have anabolic actions in protein metabolism in differentiated muscle, which remains to be investigated. In light of the results of this in vitro study, it is not surprising that no significant effects on skeletal muscle were apparent after supplementing sows during gestation with pure daidzein (16) in a concentration contained in typical soy-based diets result- ing in circulating concentrations of approximately $1 \mu \mathrm{M}(14)$. In general, inhibition of proliferation was observed with isoflavone concentrations between 10 and $100 \mu \mathrm{M}$, which correspond to the maximum daily uptake by infants fed soybased diets or to isoflavone concentrations often used in cancer prevention studies. Using both genistein and daidzein within identical experiments, we were able to show that genistein has a stronger potential to inhibit porcine muscle cell growth. Growth inhibition mostly resulted from DNA damage and cell death. Finally, the DNA damaging effects observed appear to be partially reversible, as demonstrated by the occurrence of DNA repair. In conclusion, the detrimental effects of isoflavones on skeletal muscle cell growth are to be expected at circulating concentrations of greater than $1 \mu \mathrm{M}$, provided that these are identical with those concentrations reaching the target tissue.

Acknowledgments. The authors acknowledge Angela Steinborn, Hilke Brandt, and Marie Jugert-Lund for their skilled technical assistance.

\section{REFERENCES}

1. Barrett J. Phytoestrogens. Friends or foes? Environ Health Perspect 1996;104:478 482

2. Whitten PL, Patisaul HB 2001 Cross-species and interassay comparisons of phytoestrogen action. Environ Health Perspect 109:5-20

3. Kurzer MS, Xu X 1997 Dietary phytoestrogens. Annu Rev Nutr 17:353-381

4. Kinjo J, Tsuchihashi R, Morito K, Hirose T, Aomori T, Nagao T, Okabe H, Nohara T, Masamune Y 2004 Interactions of phytoestrogens with estrogen receptors alpha and beta (III). Estrogenic activities of soy isoflavone aglycons and their metabolites isolated from human urine. Biol Pharm Bull 27:185-188

5. Ren MQ, Kuhn G, Wegner J, Chen J 2001 Isoflavones, substances with multibiological and clinical properties. Eur J Nutr 40:135-146

6. Akiyama T, Ishida J, Nakagawa S, Ogawara H, Watanabe S, Itoh N, Shibuya M, Fukami Y 1987 Genistein, a specific inhibitor of tyrosine-specific protein kinases. J Biol Chem 262:5592-5595

7. Chen AC, Donovan SM 2004 Genistein at a concentration present in soy infant formula inhibits Caco-2BBe cell proliferation by causing G2/M cell cycle arrest. J Nutr 134:1303-1308

8. Yu Z, Li W, Liu F 2004 Inhibition of proliferation and induction of apoptosis by genistein in colon cancer HT-29 cells. Cancer Lett 215:159-166

9. Matsukawa Y, Marui N, Sakai T, Satomi Y, Yoshida M, Matsumoto K, Nishino H, Aoike A 1993 Genistein arrests cell cycle progression at G2-M. Cancer Res 53:1328-1331

10. Ji S, Willis GM, Frank GR, Cornelius SG, Spurlock ME 1999 Soybean isoflavones, genistein and genistin, inhibit rat myoblast proliferation, fusion and myotube protein synthesis. J Nutr 129:1291-1297

11. Salti GI, Grewal S, Mehta RR, Das Gupta TK, Boddie AW, Constantinou AI 2000 Genistein induces apoptosis and topoisomerase II-mediated DNA breakage in colon cancer cells. Eur J Cancer 36:796-802

12. Markovits J, Linassier C, Fosse P, Couprie J, Pierre J, Jacquemin-Sablon A, Saucier JM, Le Pecq JB, Larsen AK 1989 Inhibitory effects of the tyrosine kinase inhibitor genistein on mammalian DNA topoisomerase II. Cancer Res 49:5111-5117

13. Polkowski K, Mazurek AP 2000 Biological properties of genistein. A review of in vitro and in vivo data. Acta Pol Pharm 57:135-155

14. Kuhn G, Hennig U, Kalbe C, Rehfeldt C, Ren MQ, Moors S, Degen GH 2004 Growth performance, carcass characteristics and bioavailability of isoflavones in pigs fed soy bean based diets. Arch Anim Nutr 58:265-276

15. Ren MQ, Kuhn G, Wegner J, Nurnberg G, Chen J, Ender K 2001 Feeding daidzein to late pregnant sows influences the estrogen receptor beta and type 1 insulin-like growth factor receptor mRNA expression in newborn piglets. J Endocrinol 170:129135

16. Rehfeldt C, Adamovic I, Kuhn G 2007 Effects of dietary daidzein supplementation of pregnant sows on carcass and meat quality and skeletal muscle cellularity of the progeny. Meat Sci 75:103-111

17. Stopper H, Schmitt E, Kobras K 2005 Genotoxicity of phytoestrogens. Mutat Res 574:139-155

18. Jones KL, Harty J, Roeder MJ, Winters TA, Banz WJ 2005 In vitro effects of soy phytoestrogens on rat L6 skeletal muscle cells. J Med Food 8:327-331

19. Hashimoto N, Ogashiwa M, Iwashita S 1995 Role of tyrosine kinase in the regulation of myogenin expression. Eur J Biochem 227:379-387

20. Chen AC, Berhow MA, Tappenden KA, Donovan SM 2005 Genistein inhibits intestinal cell proliferation in piglets. Pediatr Res 57:192-200 
21. Kalbe C, Mau M, Wollenhaupt K, Rehfeldt C 2007 Evidence for estrogen receptor alpha and beta expression in skeletal muscle of pigs. Histochem Cell Biol 127:95107

22. Harper JM, Soar JB, Buttery PJ 1987 Changes in protein Metabolism of ovine primary muscle cultures on treatment with growth hormone, insulin, insulin-like growth factor I or epidermal growth factor. J Endocrinol 112:87-96

23. Roe JA, Harper JM, Buttery PJ 1989 Protein metabolism in ovine primary muscle cultures derived from satellite cells: effects of selected peptide hormones and growth factors. J Endocrinol 122:565-571

24. Doumit ME, Cook DR, Merkel RA 1996 Testosterone up-regulates androgen receptors and decreases differentiation of porcine myogenic satellite cells in vitro. Endocrinology 137:1385-1394

25. Rehfeldt C, Walther K 1997 A combined assay for DNA, protein, and the incorporation of $\left[{ }^{3} \mathrm{H}\right]$ label in cultured muscle cells. Anal Biochem 251:294-297

26. Löhrke B, Viergutz T, Shahi SK, Pohland R, Wollenhaupt K, Goldammer T, Walzel H, Kanitz W 1998 Detection and functional characterisation of the transcription factor peroxisome proliferator-activated receptor gamma in lutein cells. J Endocrinol 159:429-439

27. Legrand C, Bour JM, Jacob C, Capiaumont J, Martial A, Marc A, Wudtke M, Kretzmer G, Demangel C 1992 Lactate dehydrogenase (LDH) activity of the cultured eukaryotic cells as marker of the number of dead cells in the medium. J Biotechnol 25:231-243
28. Roche JF, Quirke JF 1986 The effects of steroid hormones and xenobiotics on growth of farm animals. In: Buttery PJ, Lindsay DB, Haynes NB (eds) Control and Manipulation of Animal Growth. Butterworths, London, p 39

29. Hung DT, Jamison TF, Schreiber SL 1996 Understanding and controlling the cell cycle with natural products. Chem Biol 3:623-639

30. Downes CS, Clarke DJ, Mullinger AM, Gimenez Abian JF, Creighton AM, Johnson RT 1994 A topoisomerase II-dependent G2 cycle checkpoint in mammalian cells. Nature 372:467-470

31. Linassier C, Pierre M, Le Pecq JB, Pierre J 1990 Mechanisms of action in NIH-3T3 cells of genistein, an inhibitor of EGF receptor tyrosine kinase activity. Biochem Pharmacol 39:187-193

32. Kim EJ, Shin HK, Park JH 2005 Genistein inhibits insulin-like growth factor-I receptor signaling in HT-29 human colon cancer cells: a possible mechanism of the growth inhibitory effect of genistein. J Med Food 8:431-438

33. Bai J, Sata N, Nagai H, Wada T, Yoshida K, Mano H, Sata F, Kishi R 2004 Genistein-induced changes in gene expression in Panc 1 cells at physiological concentrations of genistein. Pancreas 29:93-98

34. Cassidy A 1999 Potential tissue selectivity of dietary phytoestrogens and estrogens. Curr Opin Lipidol 10:47-52

35. Constantinou A, Kiguchi K, Huberman E 1990 Induction of differentiation and DNA strand breakage in human HL-60 and K-562 leukemia cells by genistein. Cancer Res 50:2618-2624 